TURIZAM

Volume 23, Issue 1

17-33 (2019)

ORIGINAL

SCIENTIFIC PAPER

\title{
Gastronomy Museums as Sustainable Hangouts in Gastronomy Tourism: A Gastronomy Museum Proposal for Gümüşhane City, Turkey
}

\author{
Suat Akyürek ${ }^{A}$, Barış Erdem ${ }^{B}$ \\ Received: February 2019 | Accepted: April 2019 \\ DOI: 10.5937/turizam23-20717
}

\begin{abstract}
The changes occur each passing day in demands and expectations of individuals participating to tourism movements lead to formation of new market fields in tourism industry. In this context, gastronomy tourism is regarded as one of the new trends in international tourism. Having hosted a large number of civilizations throughout the history, Turkey is accepted today as one the countries having the richest cuisines in the world. However, the efforts to transfer that gastronomic diversity to future generations are still limited in Turkey. In this study, gastronomy museums were focused on and a gastronomy museum was suggested to be established for Gümüşhane province. It is expected that the determinations revealed in the study will be a model also for other regions of Turkey and lead the way to transfer the gastronomic assets of Turkey to future generations.
\end{abstract}

Keywords: Sustainable Tourism, Gastronomy, Gastronomy Museums, Gümüşhane City.

\section{Introduction}

Museums serve as a bridge from the past to the future. Likewise, gastronomy museums have an important role to pass down gastronomic values of any nation. From this aspect, gastronomy museums are described as places where modern presentation of the past takes place in the present time (Yılmaz, Şenel, 2014: 506). As being places reflecting the gastronomic identity, gastronomy museums is an effective strategy in branding and marketing of destination (Mankan, 2017a: 641). According to Bekar et al. (2017: 470), it is not satisfactory to only taste the flavours in the destination for the tourists whose main travel motivation is gastronomy. In this regard, the authors suggest that the said tourists want to get information also about history, production and preperation of the food at the destination. Chen (2018: 509) also states "tourists are not simply satisfied by the biological needs of dining, but through dining they seek to bet-

A University of Gümüşhane, Vocational School of Social Sciences, Department of Hotel, Restaurant and Catering Services, Gümüşhane Campus, Gümüşhane, Turkey; Corresponding author: suat_akyurek91@hotmail.com

B University of Balıkesir, Faculty of Tourism, Department of Recreation Management, Çağış Campus, Balıkesir, Turkey \& University of Kyrgyz-Turkish Manas, The School of Tourism and Hotel Management, Department of Tourism and Hotel Management, 56 Chyngyz Aitmatov Avenue, Bishkek, Kyrgyzstan, berdem2110@gmail.com 
ter understand a regional food culture". Likewise, Aksoy and Sezgi (2015:81) emphasize that the tourists traveling for gastronomic purposes are looking for gastronomy museums in the destinations they travel, where they can learn gastronomy history, traditions and techniques of the region.

Gastronomic elements and events developing around those, space perception, stories, landscape, activities etc. form the cultural gastronomy experience. Dining together, sharing and performing gastronomic activities constitute the social gastronomic experience (Yıldız, 2016: 35). In a study carried out by Yeşilyurt and Arıca (2018), it was identified that the experiences of tourists visiting Emine Göğüş Cuisine Museum in Gaziantep, Turkey stood out by the dimensions of education, escape, historical remindingness and experiences with employees. Besides, it was identified that the visitors had the chance to learn foods about Gaziantep food culture from the culinary museum, which they have not known before. In this regard, it can be said that gastronomy museums are important places which response the needs of tourists seeking for gastronomic experience and form cultural gastronomy experience beyond tasting the gastronomic elements.

It is important for development of tourism to evaluate tangible or non-tangible cultural heritage elements of a region by considering their usage/protection balance. Elements such as visual arts, written expressions and oral narratives, handicrafts, places, customs and traditions, daily life styles, tools and materials and cuisine culture are the main elements forming the cultural heritage. Accordingly, passing down this cultural heritage and presenting it to visitors as a touristic product is an important issue (Düzgün, Çalık, 2017: 125-126). Cultural richnesses that create an important element of attraction for destinations should be introduced and presented as touristic product. Gastronomy is one of the leading elements that reflect the culture of a destination. Under sustainable tourism, the gastronomy tourism is an important type of tourism. Particularly the food culture standing out in tourism makes important contributions to alternative tourism studies and sustainability of region's resources (Yüncü, 2010: 28).

Gastronomy, which is one of the basic elements of culture, is also an important sign of regional and ethnic identity. Gastronomy encompasses many components in the context of cultural heritage. Folklore, religion, language, familial bonds, social structures, environmental determinism, celebrations and ceremonies, landscapes, culinary routes, smells and tastes are some of them (Timothy, 2016). Gastronomy museums are important cultural places where cuisine culture is reflected with visual presentations, written expressions and oral narratives, exhibiting and maintaining traditional production methods and kitchen tools of the past. Thus, Şahinoğlu (2015) emphasizes that culinary museums are important in maintaining non-tangible cultural heritage. Likewise, Williams (2013) expresses that gastronomy museums assume important roles in transferring cuisine culture to next generations.

With a rich background, Turkish cuisine is an indispensable part of the Turkish history. During the historical process, Turks have always been in interaction with different cultures at different locations. Therefore, Turkish cuisine has managed to be included among the richest cuisines of the world with its variety of food, cooking and storage techniques (Günyel et al., 2018). With such historical features coming from the past, almost every city in Turkey has a unique cuisine culture. One of these cities is Gümüşhane. It is considered that a gastronomy museum to be established in Gümüşhane will assume important roles in transferring cuisine culture to next generations. Associating rich cuisine culture of a region or a city to its original resource and handing it down to next generations requires sort of an intermediary power to carry the values of that cuisine's cultural evolution to this generation (Günyel et al., 2018). It may be suggested that nowadays, gastronomy museums have the potential to serve this pur- 
pose. Hence, in a study carried out by Akyürek and Zeybek (2018); the requirement to open gastronomy museum was pointed out in order to increase touristic production diversity of Gümüşhane city and develop it in terms of gastronomy tourism. Besides, another element that makes this study important is the studies about gastronomy museums in the relevant domestic and international literature, which are still limited (Mankan, 2017a: 645).

Within the scope of all these issues, the purpose of this study is to evaluate general conditions of gastronomic museums both around the world and in Turkey which contribute to sustainable tourism and create a gastronomic source of attraction at destinations for tourists and offer a gastronomy museum for Gümüşhane city. The study is expected to contribute development of sustainable tourism in Gümüşhane and enrichment of touristic product diversity of the city.

\section{Gastronomy Tourism}

The origin of gastronomy tourism depends on agriculture, culture and tourism. The combination of these three elements have allowed gastronomy tourism create source of attraction for destination and marketing of that destination. Agriculture presents the product while culture reflects authenticism and history. Thanks to tourism, these can be presented to tourists (Yüncü, 2010: 29).

According to Kivela and Crotts (2005), gastronomy is described as "the entire food, food preparation techniques and dining habits of a country or region, which separates the cuisine of that country from other cuisines". Gastronomy tourism is a tourism movement which creates traveling motivation to experience a new eating and drinking experience and considerably helps to stimulate traveling behaviors (Solak, 2016: 2). Çalışkan and Yılmaz (2016: 34-35) list the benefits of gastronomy tourism as follows:

- Forms a basis in differentiating of destination.

- Has an important role in destination marketing.

- Used as an important factor in promotion of destinations.

- Can be a traveling motivation for tourists.

- Can be influential in destination choosing of tourists.

- Can be effective for tourists in revisiting the destination.

- Can contribute to satisfaction of tourists.

- Contributes to economic development of destinations.

The main gastronomy products which can be evaluated under gastronomy tourism are shown in Table 1. Based on the information in Table 1, it can be said that gastronomy museums are described as one of the main gastronomy products forming the gastronomy tourism. 
Table 1. Basic Gastronomic Supply Resources Forming Gastronomy Tourism

\begin{tabular}{|c|c|c|c|}
\hline FACILITIES & ACTIVITIES & EVENTS & ORGANIZATIONS \\
\hline $\begin{array}{l}\text { Buildings/Structures } \\
\text { Food processing facilities, } \\
\text { wineries, breweries, farmers' } \\
\text { markets, food stores, food- } \\
\text { related museums, restaurants, } \\
\text { cafes etc. }\end{array}$ & $\begin{array}{l}\text { Consumption } \\
\text { Dining at restaurants, picnics } \\
\text { utilizing locally-grown produce, } \\
\text { purchasing retail food and } \\
\text { beverages, pick-your own } \\
\text { operations (e.g; tourists picking } \\
\text { up their own strawberries for a } \\
\text { strawberry cake in a hotel and } \\
\text { making their own cake). }\end{array}$ & $\begin{array}{l}\text { Consumer Shows } \\
\text { Food and wine shows, cooking } \\
\text { equipment, kitchen shows, } \\
\text { workshop of a famous chef, } \\
\text { product launches etc. }\end{array}$ & $\begin{array}{l}\text { Restaurant/cafe classification } \\
\text { or certification systems (e.g; } \\
\text { Michelin, Taste of Nova Scotia, } \\
\text { Harden's, Zagat, Forbes Travel } \\
\text { Guide etc.), associations } \\
\text { (Slow Food, cooks and chefs } \\
\text { federations, gastronomy } \\
\text { associations etc.) }\end{array}$ \\
\hline $\begin{array}{l}\text { Land Uses } \\
\text { Farms, orchards (fruits, } \\
\text { vegetables, lavender, olives, } \\
\text { tea, nuts etc.), vineyards etc. }\end{array}$ & $\begin{array}{l}\text { Touring } \\
\text { Wine regions, agricultural } \\
\text { regions and city food districts. }\end{array}$ & $\begin{array}{l}\text { Festivals } \\
\text { Food festivals, wine festivals, } \\
\text { harvest festivals, beer } \\
\text { festivals, mushrooms festivals, } \\
\text { seafood festivals etc. }\end{array}$ & \\
\hline $\begin{array}{l}\text { Routes and Trails } \\
\text { Wine routes, food routes, } \\
\text { gourmet trails etc. }\end{array}$ & $\begin{array}{l}\text { Education/Observation } \\
\text { Cooking schools, wine tasting/ } \\
\text { education, visiting wineries, } \\
\text { observing chef competitions, } \\
\text { reading food, beverage } \\
\text { magazines and books, testing } \\
\text { new recipes etc. }\end{array}$ & $\begin{array}{l}\text { Fairs } \\
\text { Agriculture fairs, food fairs, } \\
\text { tea fairs, apiculture fairs etc. }\end{array}$ & \\
\hline
\end{tabular}

Source: Ignatov and Smith, 2006: 240; Smith and Xiao, 2008: 290.

\section{Gastronomy Tourism in the Context of Sustainable Tourism}

Today, the interest towards gastronomy is on the rise gradually, and each passing day; a new scientific study develops in the field of gastronomy. Correspondingly, gastronomic tourism diversity is tried to be increased in order to get more share from gastronomy tourism which is an important source of traveling motivation. Besides, providing sustainability of gastronomy tourism is another important issue (Akdağ et al., 2016). Kyriakaki et al. (2016: 237) suggest that introducing the gastronomy of a region contributes to sustainability of that region. In this regard, gastronomy museums have an important place under sustainable gastronomy tourism and in terms of gastronomic product diversity. A type of gastronomy tourism in terms of sustainability might be the eco-gastronomy. Eco-gastronomy can be described as a type of tourism that provides production and sales of local food as well as preservation of traditional cuisine tools, materials and equipment together with traditional preparation, cooking and storage methods, and transferring them to future generations (Scarpato, 2002: 139-140). Şimşek and Akdağ (2017: 354) described sustainable gastronomy as promoting cultural elements of dining in connection with environmental and socio-cultural reasons and transferring them to future generations.

\section{Sustainable Tourism and Gastronomy Museums}

Museums are one of the most visited places in Europe. Particularly, more than half of the tourists traveling to countries i.e. France, Italy, Spain, England visit museums. Increase in scale, types and quality of museums has a positive effect in the number of overnight stay of tourists at the destination (Şener, 2016: 28-29). In this regard, it can be said that museums have direct and indirect effect to increase income at touristic destinations. Museums are defined 
as the places which are always at the service of society without usually seeking profit, provide development of the society, collect tangible evidence for humans and the environment, save and offer those evidences and consequently provide education and entertainment opportunities (Sezgin et al., 2011: 202). Karataş (2011: 3) defines museums as the places where any kind of objects are exhibited under scientific rules, that increase the liking and cultural accumulation of people, that offers data for relevant researches, where historical data are transferred to future generations and finally; that create a touristic demand for the region they are in.

Museums have three important functions in general which are protection (keeping, storing, accumulation, repairing, using, architectural design), research (scientific studies, articles, discussions, presentations) and communication (Kervankıran, 2014: 349-350). In this regard, gastronomy museums also can be described as the places protecting the cuisine culture of a region, giving information for the cuisine culture and conveying the cuisine culture of that region in the best way.

There are 331 visit able units of the Ministry of Culture and Tourism Directorate General of Cultural Assets and Museums serving In Turkey; 193 of which are museums and 138 are organized ruins. Besides, there are also museums with private museum status which are usually run by municipalities, chambers of commerce, governorships, district governorships and private entrepreneurs (internet 1).

Gastronomy museums are an important indication that point out development of gastronomy tourism at a destination. Tourists traveling for gastronomy purpose want to visit these gastronomy museums at the destinations they go, which they can obtain information about the history of foods, traditions regarding foods and beverages and their production techniques (Küçükkömürler et al., 2018: 83). Gastronomy museums constitute an important source of attraction at the destinations in terms of helping cuisine culture become a touristic marketing production (Bekar et al., 2017: 468). With its structure that holds together different disciplines, the gastronomy museum concept does not only include being a museum, but it also implies cultural places that is made of combining the disciplines such as agriculture, food industry, human sciences and social sciences, archeology, ethnography, art history and geography with gastronomy and culinary arts (internet 2). According to Timothy (2016:1) "food and foodways, including hunting, gathering, agriculture, aliment preparation and consumption, are an extremely important part of cultural heritage". In this context, as a result of gathering and presenting this cultural heritage in a certain place, gastronomy museums occur.

Yılmaz and Şenel (2014) have reviewed gastronomy museums under four topics which are based on cultural heritage, based on industrial heritage, based on rural tourism and based on popular culture. In this study also, the themes of museums in Table 3 and Table 4 were reviewed and the following classification was made.

1. Agricultural focused gastronomy museums: The content of such museums generally consist of agricultural products, agricultural product equipments and agricultural product areas.

2. Beverage focused gastronomy museums: They are the museums which inform visitors about wine production in particular, but also for the stages i.e. production, packaging and storing of beverages such as tea, coffee, apple juice, cola and beer.

3. Gastronomy museums focused on cuisine culture: They are the museums which reflect cuisine culture (cuisine tools and equipments, foods, table etc.) of the area they are located.

4. Museums focusing on production areas: It is usually the transformation of food and beverage production areas into museums. Examples for such museums include salt pits, olive oil factories, wind-water mills, honey production etc. 
When the relevant domestic and international literature are revealed, it is seen that there are limited studies focusing on gastronomy museums. The studies which are available in the literature on gastronomy museums are summarized in Table 2.

Table 2. Previous Studies on Gastronomy Museums

\begin{tabular}{|c|c|c|c|}
\hline Researcher(s) & Research Type & Type of Study & Subject of the Study and Main Findings \\
\hline Sezen, 2018 & Qualitative & Book Chapter & $\begin{array}{l}\text { In the study, the relation of museum and gastronomy was reviewed. Besides, } \\
\text { information was given about gastronomy museums in Turkey and around the } \\
\text { world. }\end{array}$ \\
\hline $\begin{array}{l}\text { Yeşilyurt and } \\
\text { Arıca, } 2018\end{array}$ & Qualitative & Article & $\begin{array}{l}\text { In this study, the comments of tourists on Tripadvisor.com website, who } \\
\text { visited Emine Göğüş Culinary Museum in Gaziantep, were reviewed through } \\
\text { content analysis. Following the analysis, it was identified that experiences of } \\
\text { culinary museum visitors stood out by the dimensions of education, escape, } \\
\text { historical remindingness and experiences with employees. }\end{array}$ \\
\hline $\begin{array}{l}\text { Şahin and } \\
\text { Aydın, } 2017\end{array}$ & Qualitative & Article & $\begin{array}{l}\text { Purpose of the study is to emphasize the importance of gastronomy } \\
\text { museums as a cultural and gastronomic value. In this scope, Kuşadası } \\
\text { Oleatrium Museum was focused on. In the study, it was emphasized that } \\
\text { gastronomy museums contribute to development of gastronomy tourism } \\
\text { in the region they are in, carry out promotion of the region's products and } \\
\text { consequently create an economic gain. }\end{array}$ \\
\hline $\begin{array}{l}\text { Serinkaya, } \\
2017\end{array}$ & Qualitative & Article & $\begin{array}{l}\text { In the study, spatial and social reflections of Gaziantep culinary culture in } \\
\text { traditional houses were reviewed under Emine Göğüş Culinary Museum. }\end{array}$ \\
\hline $\begin{array}{l}\text { Bekâr, Arman } \\
\text { and Sürücü, } \\
2017\end{array}$ & Qualitative & Article & $\begin{array}{l}\text { In the study, a review was made for the usage of Marmaris Bal Evi (Honey } \\
\text { House) - active as gastronomy museum - as an element of attraction and } \\
\text { its contribution to the region's tourism activities. According to the findings } \\
\text { obtained, it was concluded that Marmaris Bal Evi has increased the tourism } \\
\text { demand towards the region it is in, and that promotion of honeydew at the } \\
\text { international platform had an important role in branding efforts of Marmaris. }\end{array}$ \\
\hline $\begin{array}{l}\text { Mankan, } \\
2017 b\end{array}$ & Qualitative & Article & $\begin{array}{l}\text { Purpose of the study is to know and introduce gastronomy museums around } \\
\text { the world. Twenty gastronomy museums from different countries were } \\
\text { reviewed in this scope. }\end{array}$ \\
\hline $\begin{array}{l}\text { Mankan, } \\
2017 a\end{array}$ & Qualitative & Article & $\begin{array}{l}\text { In the study, the importance of gastronomy museums in Turkey and around } \\
\text { the world was focused on. Eight gastronomy museums from Turkey were } \\
\text { reviewed in this scope. }\end{array}$ \\
\hline Timothy, 2016 & Qualitative & Book Chapter & $\begin{array}{l}\text { In the study, the destinations were evaluated in the context of food which is } \\
\text { an element of cultural heritage and its relation with gastronomy museums } \\
\text { was revealed. However, some of the gastronomic museums in the world are } \\
\text { given as examples in the study. }\end{array}$ \\
\hline $\begin{array}{l}\text { Sormaz and } \\
\text { Güneş, } 2016\end{array}$ & Qualitative & Article & In the study, four gastronomy museums located in Turkey were reviewed. \\
\hline $\begin{array}{l}\text { Şahinoğlu, } \\
2015\end{array}$ & Quantitative & Thesis & $\begin{array}{l}\text { Purpose of the study is to point out more to Turkish culinary culture under } \\
\text { non-tangible cultural heritage. In this regard, questionnaire was applied to } \\
\text { visitors of the culinary museums in Turkey. In the study, it was emphasized } \\
\text { that culinary museums were important in maintaining non-tangible cultural } \\
\text { heritage. }\end{array}$ \\
\hline $\begin{array}{l}\text { Yılmaz and } \\
\text { Şenel, } 2014\end{array}$ & Qualitative & Proceeding & $\begin{array}{l}\text { In the study, samples of gastronomy museums were given from Turkey and } \\
\text { the world, and gastronomy museums were classified according to different } \\
\text { functions they have. }\end{array}$ \\
\hline Williams, 2013 & Qualitative & Book Chapter & $\begin{array}{l}\text { In this study, the importance of food museums was focused on. In this } \\
\text { scope, it was emphasized that food museums were important in protecting } \\
\text { the elements related to eating-drinking and in transferring them to future } \\
\text { generations, that they offered different experiences to their visitors, and that } \\
\text { there would be an increase in food museums in the future. }\end{array}$ \\
\hline
\end{tabular}




\begin{tabular}{|l|l|l|l|}
\hline Researcher(s) & Research Type & Type of Study & Subject of the Study and Main Findings \\
\hline Yağar, 2012 & Qualitative & Thesis & $\begin{array}{l}\text { In the study, the culinary culture of Antalya city was stated, and a culinary } \\
\text { museum offer for Antalya was developed. }\end{array}$ \\
\hline Koz, 2009 2011 & Qualitative & Thesis & $\begin{array}{l}\text { In the study, gastronomy museums were discussed under design. In this } \\
\text { regard, the design of a museum at National Mall of Washington D.C. was } \\
\text { focused on. Following the study, an interactive experience relation between } \\
\text { architectural design, food, human and design was revealed. }\end{array}$ \\
& Qualitative & Thesis & $\begin{array}{l}\text { In the study, it was mentioned how the culinary culture would be involved in } \\
\text { museums and the properties of culinary museums were stated, besides; the } \\
\text { palace and cuisine concepts were emphasized, and recommendations were } \\
\text { developed about how palace cuisines would be utilized within these functions. }\end{array}$ \\
\hline
\end{tabular}

When Table 2 is reviewed, it is observed that the studies conducted related to gastronomy museums show increase in recent years. However, qualitative approach was usually adopted in the conducted studies. When the studies are reviewed, it is seen that article type studies are usually predominant.

Although there is no clear information about the number of gastronomy museums, it is suggested that there are more than 150 gastronomy-themed museums today in many different countries, which are deemed as a point of attraction for tourists (Mankan, 2017b: 159). In Table 3, some gastronomy museums in the world are presented.

Table 3. Some of Gastronomy Museums around the World

\begin{tabular}{|c|c|c|c|}
\hline Museum's Name & Country & Theme & Internet Access Address \\
\hline $\begin{array}{l}\text { 1. Southern Food \& } \\
\text { Beverage Museum }\end{array}$ & USA & Culinary culture & https://natfab.org/southern-food-and-beverage/ \\
\hline $\begin{array}{l}\text { 2. Agricultural and Cotton } \\
\text { Museum }\end{array}$ & Egypt & Agricultural-plant-cotton & https://www.thecottonmuseum.com/en \\
\hline $\begin{array}{l}\text { 3. Amsterdam Cheese } \\
\text { Museum }\end{array}$ & Netherlands & Cheese & http://www.cheesemuseumamsterdam.com/ \\
\hline $\begin{array}{l}\text { 4. Shin-Yokohama Ramen } \\
\text { Museum }\end{array}$ & Japan & $\begin{array}{l}\text { Ramen } \\
\text { (name in Japanese noodles) }\end{array}$ & http://www.raumen.co.jp/ \\
\hline 5. Chocolate Museum & France & Chocolate & http://www.museeduchocolat.fr/ \\
\hline $\begin{array}{l}\text { 6. American Museum of } \\
\text { Baking }\end{array}$ & USA & Biography of baking & $\begin{array}{l}\text { http://www.cityprofile.com/kansas/american- } \\
\text { museum-of-baking.html }\end{array}$ \\
\hline 7. The Beer Can Museum & USA & Beer can & http://www.beercanhouse.org/about.php \\
\hline 8. Bochnia Salt Mine & Poland & Salt mine & http://kopalnia-bochnia.pl/ \\
\hline $\begin{array}{l}\text { 9. Bramah Tea \& Coffee } \\
\text { Museum }\end{array}$ & England & Tea and coffee & http://www.teaandcoffeemuseum.co.uk/ \\
\hline 10. Cadbury World Museum & England & Chocolate & https://www.cadburyworld.co.uk/en \\
\hline $\begin{array}{l}\text { 11. China National Tea } \\
\text { Museum }\end{array}$ & China & Tea & $\begin{array}{l}\text { http://en.chnmuseum.cn/default. } \\
\text { aspx?AspxAutoDetectCookieSupport=1 }\end{array}$ \\
\hline 12. Vidalia Onion Museum & USA & Onion & http://www.vidaliaonion.org/ \\
\hline 13. Choco-Story & Belgium & $\begin{array}{l}\text { Chocolate and books about } \\
\text { chocolate }\end{array}$ & http://choco-story-brugge.be/ \\
\hline 14. The Chocolate Museum & Canada & Chocolate & http://www.chocolatemuseum.ca/ \\
\hline 15. Cider museum & England / Spain & Cider & $\begin{array}{l}\text { https://www.museodelasidra.com/ } \\
\text { https://www.cidermuseum.co.uk/ }\end{array}$ \\
\hline 16. Museum Coca-Cola & USA & Cola and cola can & https://www.worldofcoca-cola.com/ \\
\hline
\end{tabular}




\begin{tabular}{|c|c|c|c|}
\hline Museum's Name & Country & Theme & Internet Access Address \\
\hline 17. Napa-Copia Museum & USA & Wine & http://www.ciaatcopia.com/ \\
\hline 18. The Cyprus Wine Museum & South Cyprus & Wine & https://www.cypruswinemuseum.com/ \\
\hline 19. European Bread Museum & Germany & Bread & http://www.brotmuseum.de/ \\
\hline 20. The Frietmuseum & Peru & Everything about Potatoes & http://www.frietmuseum.be/en/ \\
\hline 21. Deutsches Salzmuseum & Germany & Salt & http://www.salzmuseum.de/ \\
\hline 22. The Gingerbread Museum & Poland & Flour production-bread & http://gingerbreadmuseum.cz/cz/ \\
\hline 23. The Goa Chitra Museum & India & $\begin{array}{l}\text { Farm equipment and } \\
\text { culinary culture }\end{array}$ & http://www.goachitra.com/ \\
\hline 24. Culinary Arts Museum & USA & $\begin{array}{l}\text { Everything about the } \\
\text { kitchen }\end{array}$ & https://www.culinary.org/ \\
\hline 25. Museo dell'Olivo & Italy & Olive and olive oil & http://www.museodellolivo.com/ \\
\hline $\begin{array}{l}\text { 26. Museum of Greek } \\
\text { Gastronomy }\end{array}$ & Greece & Greek gastronomy & https://www.gastronomymuseum.gr/services \\
\hline 27. Gastronomy Museum & Czech Republic & Dining and modern kitchen & http://www.muzeumgastronomie.cz/en/home \\
\hline $\begin{array}{l}\text { 28. Swiss Gastronomy } \\
\text { Museum }\end{array}$ & Switzerland & Food and drink culture & https://gastronomiemuseum.ch/ \\
\hline 29. Bully Hill Vineyards & USA & Wine & https://www.bullyhillvineyards.com/ \\
\hline $\begin{array}{l}\text { 30. European Asparagus } \\
\text { Museum }\end{array}$ & Germany & Asparagus & $\begin{array}{l}\text { https://www.atlasobscura.com/places/ } \\
\text { european-asparagus-museum }\end{array}$ \\
\hline 31. Butter Museum, & Ireland & Butter & http://thebuttermuseum.com/about \\
\hline $\begin{array}{l}\text { 32. Museum of Prosciutto di } \\
\text { Parma }\end{array}$ & Italy & Culinary Culture & $\begin{array}{l}\text { http://www.turismo.comune.parma.it/en/ } \\
\text { thematic-channels/flavors/food-and-wine- } \\
\text { factories/museum-of-prosciutto-di-parma }\end{array}$ \\
\hline 33. The World Carrot Museum & Belgium & Carrot & http://www.carrotmuseum.co.uk/ \\
\hline 34. Poznan Croissant Museum & Poland & Pastries & $\begin{array}{l}\text { http://rogalowemuzeum.pl/en/o-muzeum/\#w- } \\
\text { skrocie }\end{array}$ \\
\hline 35. Brazil's Coffee Palace & Brazil & Coffee & http://www.museudocafe.org.br/en/ \\
\hline 36. Russian Vodka Museum & Russia & Vodka & $\begin{array}{l}\text { http://stroganoffgroup.ru/restaurants/muzey- } \\
\text { russkoy-vodki/ }\end{array}$ \\
\hline $\begin{array}{l}\text { 37. Barbayannis Ouzo } \\
\text { Museum }\end{array}$ & Greece & Ouzo & $\begin{array}{l}\text { https://www.greeka.com/eastern_aegean/ } \\
\text { lesvos/lesvos-museums/barbayannis-ouzo- } \\
\text { museum.htm }\end{array}$ \\
\hline 38. Olive Oil Museum & Italy & Olive and olive oil & $\begin{array}{l}\text { http://www.goimperia.com/the-olive-tree- } \\
\text { museum/ }\end{array}$ \\
\hline 39. Bread Museum & Portugal & Bread & http://www.museudopao.pt/ \\
\hline 40. Museum Kimchikan & South Korea & Kimchi & https://www.kimchikan.com/ \\
\hline 41. Kitchen Museum & England & Kitchen & https://www.sallylunns.co.uk/kitchen-museum/ \\
\hline
\end{tabular}

Source: Table 3 was recompiled and expanded by utilizing the article of Mankan (2017b)

When gastronomy museums in Table 3 are reviewed, it is seen that they are usually concentrated in developed countries which have an important position in tourism. Themes of the museums generally focus on culinary culture, beverage, food and beverage production areas. Museums usually have their own websites, but it is remarkable that they are also evaluated in many online comment websites such as Tripadvisor. Below can be seen some of figures of gastronomic museums around the world. 


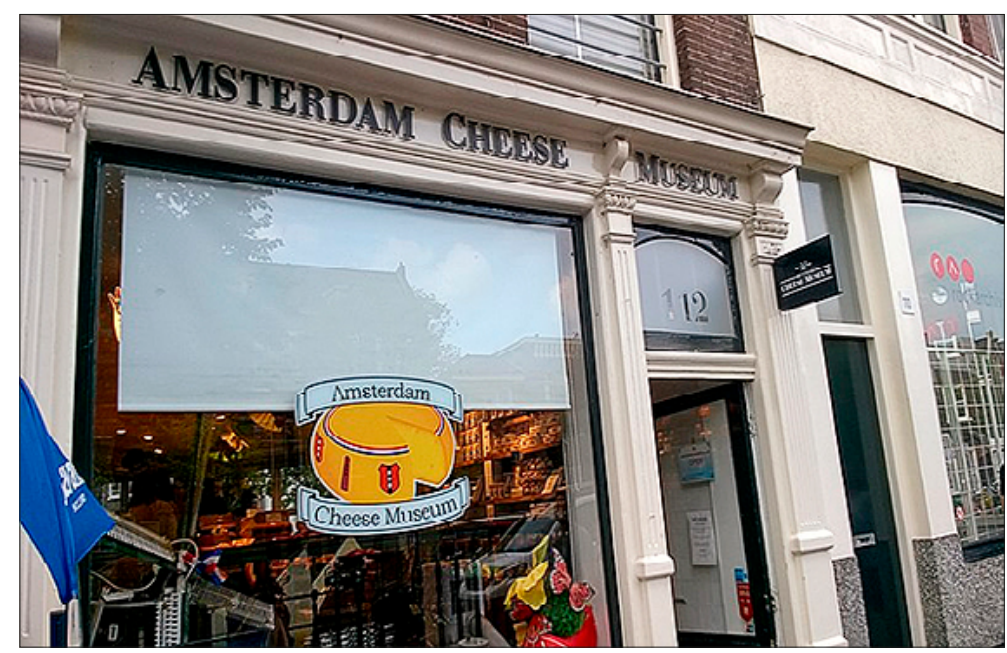

Figure 1. Exterior view of Amsterdam Cheese Museum Figure Source: internet 3

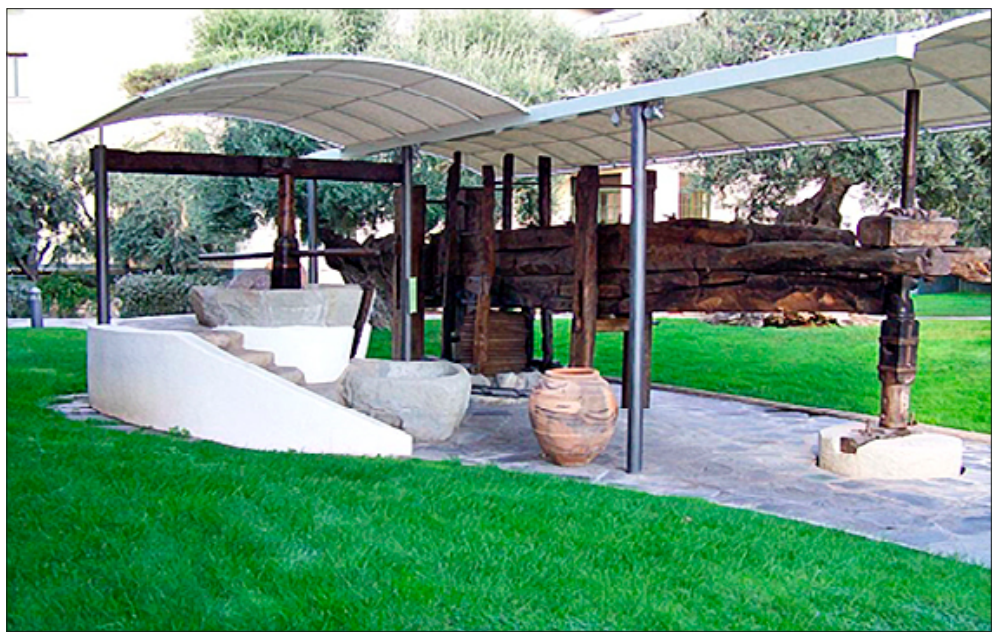

Figure 2. Exterior view of Museo dell'Olivo, Italy Source: internet 4
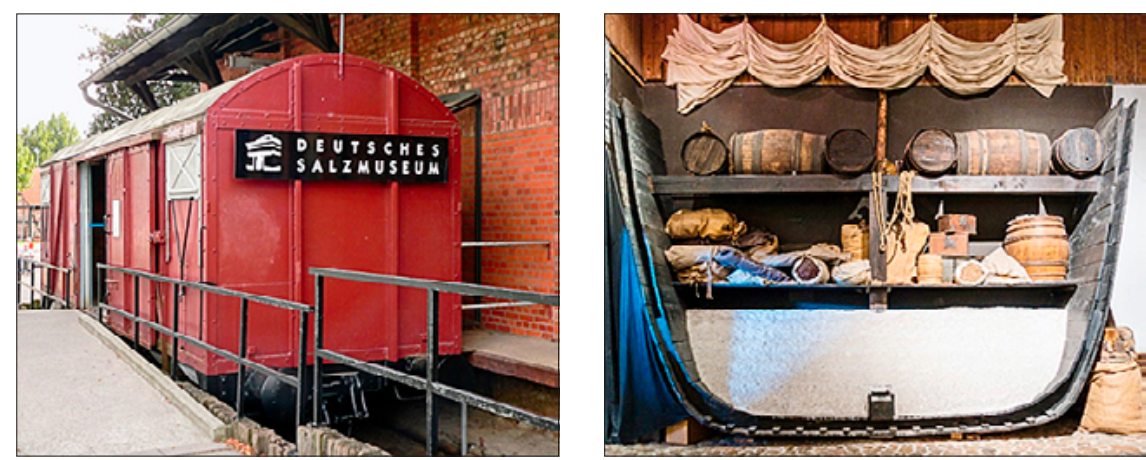

Figure 3. Exterior and interior views of Deutsches Salzmuseum, Germany Source: internet 5 , internet 6 
There are also some places in various cities of Turkey, where culinary tools and materials used in the past, regional food and production areas were brought together to be exhibited, and then transformed into museums (Sormaz and Güneș, 2016: 28). These places are presented in Table 4.

Table 4. Gastronomy Museums in Turkey

\begin{tabular}{|c|c|c|c|c|c|}
\hline Museum's Name & City & Theme & $\begin{array}{l}\text { Opening } \\
\text { Year }\end{array}$ & $\begin{array}{l}\text { Ownership } \\
\text { Status }\end{array}$ & Internet Access Address \\
\hline $\begin{array}{l}\text { Adatepe Olive Oil } \\
\text { Museum }\end{array}$ & Çanakkale & $\begin{array}{l}\text { Olive and } \\
\text { olive oil }\end{array}$ & 2001 & Private & https://www.adatepe.com/ \\
\hline Bursa City Museum & Bursa & $\begin{array}{l}\text { Culinary } \\
\text { culture }\end{array}$ & 2004 & Municipality & http://www.bursakentmuzesi.com/ \\
\hline Kutman Wine Museum & Tekirdağ & Wine & 2004 & Private & http://www.kutmansaraplari.com/ \\
\hline $\begin{array}{l}\text { Edremit Evren Ertür } \\
\text { Historical Olive Oil Tools } \\
\text { Museum }\end{array}$ & Balıkesir & $\begin{array}{l}\text { Olive and } \\
\text { olive oil }\end{array}$ & 2005 & Private & http://www.sabitertur.com.tr/ \\
\hline Bread Museum & Ankara & Bread & 2007 & Municipality & $\begin{array}{l}\text { http://www.ankarahalkekmek.com. } \\
\text { tr/EkmekMuzesi.aspx }\end{array}$ \\
\hline $\begin{array}{l}\text { Emine Göğüş Kitchen } \\
\text { Museum }\end{array}$ & Gaziantep & $\begin{array}{l}\text { Culinary } \\
\text { culture }\end{array}$ & 2008 & Municipality & $\begin{array}{l}\text { http://eminegogusmutfakmuzesi. } \\
\text { org/ }\end{array}$ \\
\hline $\begin{array}{l}\text { Atatürk Forest Farm } \\
\text { Museum and Exhibition } \\
\text { Hall }\end{array}$ & Ankara & $\begin{array}{l}\text { Wine, old } \\
\text { production } \\
\text { equipment }\end{array}$ & 2010 & $\begin{array}{l}\text { Atatürk Forest } \\
\text { Farm }\end{array}$ & $\begin{array}{l}\text { http://www.aoc.gov.tr/Portal/ } \\
\text { Geziyerlerimiz/ataturk-orman- } \\
\text { ciftligi-muze-ve-sergi-salonu/37 }\end{array}$ \\
\hline Beekeeping Museum & Muğla & $\begin{array}{l}\text { Beekeeping } \\
\text { and honey } \\
\text { products }\end{array}$ & 2010 & $\begin{array}{l}\text { Muğla Province } \\
\text { Bee Growers } \\
\text { Association }\end{array}$ & $\begin{array}{l}\text { https://www.maybir.org.tr/aricilik- } \\
\text { muzesi-tarihce }\end{array}$ \\
\hline $\begin{array}{l}\text { Hacibanlar House Kitchen } \\
\text { Museum }\end{array}$ & Şanlıurfa & $\begin{array}{l}\text { Culinary } \\
\text { culture }\end{array}$ & 2011 & Municipality & $\begin{array}{l}\text { https://www.sanliurfa.bel.tr/ } \\
\text { icerik/70/28/mutfak-muzesi }\end{array}$ \\
\hline $\begin{array}{l}\text { İstanbul Gastronomy } \\
\text { Museum }\end{array}$ & İstanbul & Culinary & - & Private & https://msa.com.tr/muze \\
\hline $\begin{array}{l}\text { Oleatrium Olive and } \\
\text { Olive Oil History Museum }\end{array}$ & Aydın & $\begin{array}{l}\text { Olive and } \\
\text { olive oil }\end{array}$ & 2011 & Private & http://www.oleatrium.com/ \\
\hline $\begin{array}{l}\text { Erzurum Houses } \\
\text { Restaurant Museum }\end{array}$ & Erzurum & $\begin{array}{l}\text { Culinary } \\
\text { culture }\end{array}$ & 2011 & Private & http://www.erzurumevleri.com/ \\
\hline Marmaris Honey House & Muğla & $\begin{array}{l}\text { Beekeeping, } \\
\text { honey }\end{array}$ & 2012 & $\begin{array}{l}\text { Marmaris } \\
\text { Chamber of } \\
\text { Commerce }\end{array}$ & http://www.marmarisbalevi.com.tr/ \\
\hline $\begin{array}{l}\text { Hatay Medical and } \\
\text { Aromatic Plants Museum }\end{array}$ & Hatay & $\begin{array}{l}\text { Medical and } \\
\text { aromatic } \\
\text { plants }\end{array}$ & 2012 & $\begin{array}{l}\text { Governorship and } \\
\text { Special Provincial } \\
\text { Administration }\end{array}$ & $\begin{array}{l}\text { http://www.hatay.gov.tr/tibbi-ve- } \\
\text { aromatik-bitkiler-muzesi }\end{array}$ \\
\hline Zavot Cheese Museum & Kars & Cheese & 2012 & $\begin{array}{l}\text { Büyük and Küçük } \\
\text { Boğatepe Village } \\
\text { Headmens }\end{array}$ & $\begin{array}{l}\text { http://coikk.com/bogatepe-koyu- } \\
\text { ve-peynir-muzesi/ }\end{array}$ \\
\hline $\begin{array}{l}\text { İncekum Caravanserai } \\
\text { and Yörük Museum }\end{array}$ & Antalya & $\begin{array}{l}\text { Yoruk culinary } \\
\text { culture }\end{array}$ & 2012 & Private & $\begin{array}{l}\text { http://www.altso.org.tr/genel/ } \\
\text { yoruk-muzesi-acildi/ }\end{array}$ \\
\hline $\begin{array}{l}\text { EGEA Olive Farming } \\
\text { Museum }\end{array}$ & Manisa & $\begin{array}{l}\text { Olive and } \\
\text { olive oil }\end{array}$ & 2013 & Private & $\begin{array}{l}\text { https://www.egea.com.tr/index. } \\
\text { php?do=dynamic/view\&pid=7 }\end{array}$ \\
\hline Pelit Chocolate Museum & İstanbul & Chocolate & 2014 & Private & $\begin{array}{l}\text { http://www.pelitcikolatamuzesi. } \\
\text { com/ }\end{array}$ \\
\hline
\end{tabular}




\begin{tabular}{|c|c|c|c|c|c|}
\hline Museum's Name & City & Theme & $\begin{array}{l}\text { Opening } \\
\text { Year }\end{array}$ & $\begin{array}{l}\text { Ownership } \\
\text { Status }\end{array}$ & Internet Access Address \\
\hline Antakya Cuisine Museum & Hatay & $\begin{array}{l}\text { Culinary } \\
\text { culture }\end{array}$ & 2017 & $\begin{array}{l}\text { Antakya Chamber } \\
\text { of Commerce and } \\
\text { Industry }\end{array}$ & $\begin{array}{l}\text { http://hataygastronomi.com/ } \\
\text { arsivler/2691 }\end{array}$ \\
\hline $\begin{array}{l}\text { Thematic Culinary } \\
\text { Museum }\end{array}$ & $\begin{array}{l}\text { Kahraman- } \\
\text { maraş }\end{array}$ & $\begin{array}{l}\text { Culinary } \\
\text { culture }\end{array}$ & 2017 & Municipality & $\begin{array}{l}\text { http://www.dulkadiroglu.bel.tr/i/ } \\
\text { mutfak-muzesi.html }\end{array}$ \\
\hline $\begin{array}{l}\text { Köstem Olive Oil } \\
\text { Museum }\end{array}$ & İzmir & Olive oil & 2017 & Private & http://kostemzeytinyagi.com/ \\
\hline $\begin{array}{l}\text { Kapurcuk Culture and } \\
\text { Gastronomy House }\end{array}$ & Muğla & $\begin{array}{l}\text { Culinary } \\
\text { culture }\end{array}$ & 2017 & Private & http://www.kapurcuk.com/ \\
\hline Turkish Flavor Museum & İstanbul & Local food & 2018 & $\begin{array}{l}\text { Many private } \\
\text { enterprises }\end{array}$ & http://turklezzetmuzesi.com/tr/ \\
\hline Adana Culinary Museum & Adana & $\begin{array}{l}\text { Culinary } \\
\text { culture }\end{array}$ & $\begin{array}{l}\text { It will } \\
\text { be open } \\
\text { soon }\end{array}$ & Municipality & $\begin{array}{l}\text { http://www.hurriyet.com.tr/ } \\
\text { yikilmaya-yuz-tutan-konak-adana- } \\
\text { mutfak-muzesi-o- } 40624941\end{array}$ \\
\hline $\begin{array}{l}\text { Mardin Gastronomy } \\
\text { Museum and Application } \\
\text { Center }\end{array}$ & Mardin & $\begin{array}{l}\text { Culinary } \\
\text { culture }\end{array}$ & $\begin{array}{l}\text { At the } \\
\text { project } \\
\text { stage }\end{array}$ & $\begin{array}{l}\text { Mardin Artuklu } \\
\text { University }\end{array}$ & $\begin{array}{l}\text { http://www.dika.org.tr/6055- } \\
\text { haberler }\end{array}$ \\
\hline $\begin{array}{l}\text { Gastronomy Museum and } \\
\text { Cultural Center }\end{array}$ & Mersin & $\begin{array}{l}\text { Culinary } \\
\text { culture }\end{array}$ & $\begin{array}{l}\text { At the } \\
\text { project } \\
\text { stage }\end{array}$ & Municipality & $\begin{array}{l}\text { http://www.milliyet.com. } \\
\text { tr/buyuksehir-belediyesi- } \\
\text { tarihi-karamancilar-mersin- } \\
\text { yerelhaber-2165439/ }\end{array}$ \\
\hline Çaykur Tea Museum & Rize & Tea & $\begin{array}{l}\text { It will } \\
\text { be open } \\
\text { soon }\end{array}$ & Çaykur Company & $\begin{array}{l}\text { http://www.tutap.com.tr/detay_ } \\
\text { tanitim/caykur-cay-muzesi/871 }\end{array}$ \\
\hline
\end{tabular}

Source: Table 4 was recompiled and expanded by utilizing the articles of Mankan (2017a) and Şahin and Aydın (2017: 184)

When Table 4 is reviewed, it is seen that there are museums representing each gastronomy museums in Turkey. According to information obtained from websites of the gastronomy museums, it is observed that gastronomy museums in Turkey have usually opened in recent years. Museums were opened through public and private entrepreneurships. It is remarkable that museums which were opened predominantly by public were usually opened through making use of supportive organizations by project planning. For the museums opened by private enterprises, it is usually considered that they got started with marketing and sales improvement purposes in the fields they produce. Below can be seen some of figures of gastronomic museums in Turkey.
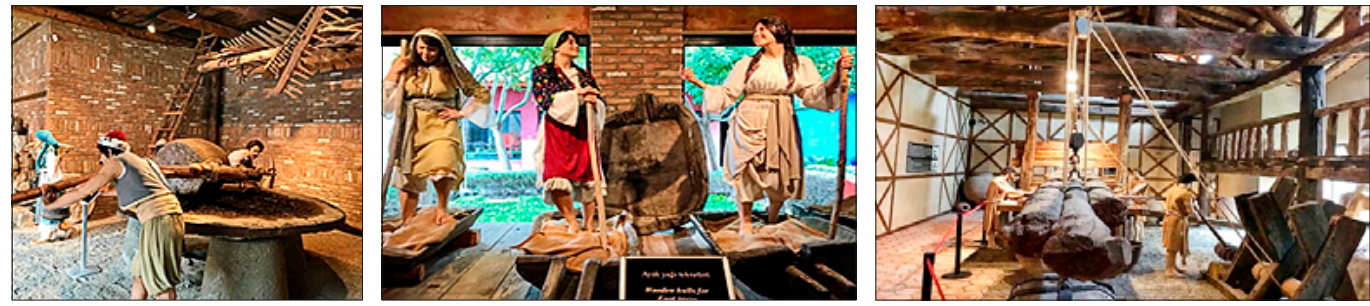

Figure 4. Interior views of Oleatrium Olive and Olive Oil History Museum, Aydın, Turkey (Photo: Suat Akyürek, March 18, 2018) 


\section{A Gastronomy Museum Proposal for Gümüşhane City}

It is known that Turkey is quite behind the European countries and the USA both in the number and income of museums and in the number of museum visitors (Kervankıran, 2014: 364). Therefore, the requirement to diversify museums and increase the number of museums shows up in Turkey, which has a rich potential in terms of number of museum resources. Despite this, the increase in the number of gastronomy museums in Turkey in recent years and that these gastronomy museums start to contribute museum diversity in the country can be considered as a positive development.

Many of the gastronomy museums in Turkey were established thanks to private initiatives of local authorities (chambers of commerce, municipalities, mukhtarships). It is particularly witnessed that these gastronomy museums are established by being designed and supplying fund from organizations providing various financial support (See: Table 4). It is likewise understood that museums are opened to reflect culinary culture of the region they are established or to inform manufacturing processes of a product that is manufactured peculiar to the region (See: Table 3). As for the museums established by private enterprises, it is understood when checking their websites that they are usually established for a commercial purpose and used as a marketing tactic. Examples for such type of museums include wine museums, olive oil museums, cheese museums etc.

The city of Gümüşhane, which is located at Black Sea region of Turkey, has a rich potential in terms of alternative tourism diversity. Besides, the city of Gümüşhane which has a structure for specific interest tourism rather than mass tourism, is a transition zone between the Black Sea and the Eastern Anatolian Regions and incorporates the cultural properties of two different regions. The different cultural structure of the city offers various eating and drinking alternatives to the region in gastronomy area. In this regard, the city has four distinctive gastronomic products. These are pestil (dried fruit rollup), köme (churchkhela), siron (baked pastry rolls with yogurt) and Gümüşhane bread (internet 7). When overall evaluated, it seems possible to open a gastronomy museum in Gümüşhane both in terms of culinary culture peculiar to the region and eating-drinking production areas peculiar to itself.

When we take a look at gastronomy museums in Turkey (See: Table 4), it is seen that there are gastronomy museums in every region. The only exception for that is the Black Sea Region. In other words, no gastronomy museum has been found in the Black Sea region. Although a new tea museum is planned to be opened in Rize city, there is no attempt to open up a museum that will reflect culinary culture of the Black Sea region. In this regard, a gastronomy museum to be opened in Gümüşhane is considered to be a pioneer museum for the region and will attract the attentions of tourists visiting the region. On the other hand, it can be predicted that a gastronomy museum to be opened in Gümüşhane will have a range of positive effects. Some of them are; increasing touristic product diversity in the city, transferring culinary culture to future generations, strengthening the image, identity and recognition of the city and enhancing cultural and recreational activity opportunities of the city. Likewise, it is thought that with a gastronomy museum to be opened in Gümüşhane will contribute to recovery of local economy through introducing Gümüşhane local products into the market. In this scope, by getting inspired from international and domestic gastronomy museums and taking gastronomic values of Gümüşhane into consideration, the recommendations to be able to establish a gastronomy museum peculiar to Gümüşhane might be as follows:

- Gümüşhane Culinary Museum Can Be Established: A museum which reflects culinary tools and materials; preparing, cooking, eating-drinking, keeping methods, foods 
and beverages, words, symbols and recipes etc. of Gümüşhane cuisine can be established. Besides, Gümüşhane table manners can be revived in the museum with wax sculptures. When the existence of historical mansions particular to Gümüşhane are considered, one of these mansions can be used for gastronomy museum. In this scope, the project by Dulkadiroğlu Municipality in 2017 to restore a historical mansion and open it up as a culinary museum (internet 8) may be a guiding project for Gümüşhane museum.

- Gümüşhane Pestil-Köme Museum Can Be Established: An idle or unused pestil-köme factory can be turned into its state during production or an old mansion can be transformed to museum in order to obtain a different income from pestil-köme which the locomotive of Gümüşhane in economy is. In the museum to be established, general information and photographs on pestil-köme production stages in traditional and industrial style and on pestil-köme production can be exhibited. A museum to be established in such type may also be opened up within a pestil-köme factory which is already active.

- A Pottery Museum Peculiar to Gümüşhane Can Be Opened Up: In order to prevent forgetting pottery which is an important traditional handicraft in Dölek village of Gümüşhane, a pot museum can be opened. In this museum, stages of pot making, and pot types can be exhibited. Thus, in the study of Çalık and Ödemiş'in (2015) which they carried out regarding sustainability of non-tangible cultural heritage elements in Gümüşhane city, the necessity to establish a pot museum was emphasized.

When evaluated overall, it is seen that there are many gastronomic values with respect to establishing a gastronomy museum in Gümüşhane. It is considered that opening up a gastronomy museum which incorporates all these gastronomic values will provide quite important opportunities for Gümüşhane tourism. Establishing such kind of a museum may trigger Gümüşhane local people, domestic and foreign tourists planning to visit Gümüşhane, students and people who are interested in gastronomy; and lead to an influx of tourists towards the city.

\section{Conclusion and Suggestions}

Gastronomy museums have an important role in order to help improvement of tourism with a sustainable approach at a destination. In this study, gastronomy museums were focused on and gastronomic values that the city has were revealed in order to establish gastronomy museum in Gümüşhane. With an overall assessment, it was observed that important gastronomic resources were present to allow establishment of gastronomy museum in Gümüşhane. A gastronomy museum to be established in Gümüşhane is predicted to contribute product diversity of the city and increase tourism demand towards the region. In this scope, the following recommendations can be provided to relevant stakeholders:

- In the examinations carried out, it was identified that gastronomy museums in Turkey were opened through municipality, chambers of commerce, various supportive institutions and private individuals. In addition to this, a culinary project appears to be conducted by the initiations of Mardin University. In this regard, after determining the most appropriate person or institution in Gümüşhane, opening up the gastronomy museum can be realized. 
- A gastronomy museum of Gümüşhane University circulating capital can be established. This museum can both help relevant departments for application/research courses and contribute to circulating capital of the university.

- The relevant departments of Gümüşhane University being in the first place, by cooperation of institutions i.e. Provincial Directorate of Culture and Tourism, governorate, municipality etc. and through other supportive organizations (DOKAP, KOSGEB, Chamber of Commerce and Industry); a new project can be conducted to open up gastronomy museum.

- Establishing the gastronomy museum will increase the diversity of the city's cultural and recreational activities. In this regard, the gastronomy museum can be thought to be established at city center or within the university.

- Especially on gastronomic routes being in the first place, opening up gastronomy museums in different cities with different themes should be promoted through relevant institutions and organizations.

- In order to sustain the products with geographic signs from various cities of Turkey and being able to obtain a different source of income from such products, gastronomy museums can be opened up by themes of those products.

- In the examinations carried out, it was remarkable that providing official figures about the exact number of gastronomy museums in Turkey was quite difficult and therefore, that the recognition of gastronomy museums was quite low. In this scope, the relevant institutions and organizations should take on important tasks for statistics and promotions of gastronomy museums. Therefore, the number of gastronomy museums should be determined as the first step and a map of gastronomy museums in Turkey should be prepared.

- Gastronomy museums in Turkey should be included in travel agency tours, particularly on gastronomy routes.

- When the studies carried out with gastronomy museums are reviewed, it is observed that either general conditions of gastronomy museums in the world and in Turkey or a certain gastronomy museum are focused on (See: Table 3 and Table 4). In this scope, considering the rich culinary culture of Turkey; conducting similar studies and projects that utilize the potential of different regions in terms of gastronomy museums can be recommended to researchers.

\section{Limitations and Suggestions for Further Researches}

The data in this study are based on secondary sources. It is thought that empirical studies to be carried out in the following researches on gastronomy museums will provide important contributions to the relevant literature. The said empirical researches can be carried out on domestic and foreign tourists who are interested in gastronomy as well as perceptions of local people and local authorities on the subject can be examined. 


\section{Acknowledgements}

This study has been presented as a proceeding in the ard International Congress on Sustainable Tourism organized by Gümüşhane University in Gümüşhane city of Turkey in the date $20-22$ September 2018 and published in the congress proceedings book.

\section{References}

Akdağ, G., Özata, E., Sormaz, Ü., Çetinsöz, B. C. 2016. Sürdürülebilir Gastronomi Turizmi İçin Yeni Bir Alternatif: Surf\&Turf. Journal of Tourism and Gastronomy Studies 4(1), 270-281 (in Turkish).

Aksoy, M., Sezgi, G. 2015. Gastronomi Turizmi ve Güneydoğu Anadolu Bölgesi Gastronomik Unsurları. Journal of Tourism and Gastronomy Studies 3(3), 79-89 (in Turkish).

Akyürek, S., Zeybek, H. İ. 2018. Gümüşhane İlinin Gastronomi Turizmi Açısından Değerlendirilmesi. Social Sciences Studies Journal (SSSJournal) 4(15), 869-882 (in Turkish).

Bekar, A., Arman, M. S., Sürücü, Ç. 2017. Turizmde Çekicilik Unsuru Olarak Gastronomi Müzeleri: Marmaris Bal Evi Örneği. Akademik Sosyal Araştırmalar Dergisi 5(42), 468-477 (in Turkish).

Chen, Z. 2018. A Pilot Study of the Co-creation Experience in Traditional Cantonese Teahouses in Hong Kong. Journal of Heritage Tourism 13(6), 506-527.

Çalık, İ., Ödemiş, M. 2015. Somut Olmayan Kültürel Miras Unsurlarının Sürdürülebilir Turizm Kapsamında Değerlendirilmesi: Gümüşhane İli Örneği. İçinde: Abdullah Kelkit, Ş. Okan Mercan, H. Mehmet Yıldırım (Editörler), 16. Ulusal Turizm Kongresi Bildiriler Kitabı, (833-843). Ankara: Detay Yayıncılık (in Turkish).

Çalışkan, O., Yılmaz, G. 2016. Gastronomy and Tourism. In: C. Avcıkurt, M. S. Dınu, N. Hacıŏglu, R. Efe, A. Soykan, N. Tetik (Eds.) Global Issues and Trends in Tourism. St. Kliment Ohridski University Press, Sofia, 33-50.

Düzgün, E., Çalık, İ. 2017. Gümüşhane İli Süleymaniye Mahallesindeki Tarihi Yapıların Sürdürülebilir Turizm Bağlamında Değerlendirilmesi. Erzincan Üniversitesi Sosyal Bilimler Enstitüsü Dergisi (ERZSOSDE), ÖS-IV, 125-136 (in Turkish).

Günyel, Ş., Turganbayeva, C., Turdubekova, S., Alimov, U., Turganbayeva, N., Samatova, G., İsakova, D. 2018. Kırgızistan ve Türkiye Mutfak Kültürü: Seçme Tarifler. Editörler: Bilgehan Gülcan, Barış Erdem ve Ramazan Eren, Ankara: Detay Yayıncılık (in Turkish).

Ignatov, E., Smith, S. 2006. Segmenting Canadian Culinary Tourists. Current Issues in Tourism 9(3), 235-255.

Karataş, A. 2011. Çevre Bilincinin Geliştirilmesinde Doğa Tarihi Müzeleri'nin Rolü. Akademik Bakış Dergisi (27), 1-15 (in Turkish).

Kervankıran, İ. 2014. Dünyada Değișen Müze Algısı Ekseninde Türkiye'deki Müze Turizmine Bakıș. Turkish Studies - International Periodical For The Languages, Literature and History of Turkish or Turkic 9(11), 345-369 (in Turkish).

Kivela, J., Crotts, C. J. 2005. Gastronomy Tourism. Journal of Culinary Science and Technology 4(2-3), 29-55.

Koz, G. F. 2009. Osmanlı Mutfak Kültürünün Saray Müzelerde Sergilenmesi. Yayımlanmamış Yüksek Lisans Tezi, Yıldız Teknik Üniversitesi Sosyal Bilimler Enstitüsü, İstanbul (in Turkish). 
Küçükkömürler, S., Şirvan, N. B., Sezgin, A. C. 2018. Dünyada ve Türkiye'de Gastronomi Turizmi. International Journal of Tourism, Economic and Business Sciences 2(2), 78-85 (in Turkish).

Kyriakaki, A., Zagkotsi, S., Trihas, N. 2016. Gastronomy, Tourist Experience and Location. The Case of the 'Greek Breakfast'. TOURISMOS: An International Multidisciplinary Refereed Journal of Tourism 11(3), 227-261.

Lam, A. 2011. Designing is Cooking: A Museum of Gastronomy. Unpublished Master's Dissertation, Virginia Polytechnic Institute, Virginia.

Mankan, E. 2017a. Destinasyon Pazarlamasında Çekici Bir Faktör Olarak Türkiye'deki Gastronomi Müzeleri Örneği. Turkish Studies - International Periodical For The Languages, Literature and History of Turkish or Turkic 12(4), 641-654 (in Turkish).

Mankan, E. 2017b. Dünyadaki Gastronomi Müzeleri Üzerine Genel Bir Değerlendirme. Turkish Studies - International Periodical For The Languages, Literature and History of Turkish or Turkic 12(1), 157-176 (in Turkish).

Scarpato, R. 2002. Sustainable Gastronomy as a Tourist Products. In: A.M. Hjalager ve G. Richards (Eds.) Tourism and Gastronomy. Routledge, London and New York, 132-152.

Serinkaya, E. Y. 2017. Mutfak Kültürünün Gaziantep'in Geleneksel Konutlarında İncelenmesi. Artium 5(1): 27-41 (in Turkish).

Sezen, T. S. 2018. Gastronomi Müzeleri. İçinde: A. Akbaba ve N. Çetinkaya (Editörler) Gastronomi ve Yiyecek Tarihi. Detay Yayıncılık, Ankara, 265-277 (in Turkish).

Sezgin, M., Haşıloğlu, S. B., İnal, E. 2011. Müze Pazarlamasında Müşteri İlişkileri ve Deneyimleri Üzerine Bir Araştırma. ZKÜ Sosyal Bilimler Dergisi 7(13), 201-220 (in Turkish).

Smith S.L.J., Xiao, H. 2008. Culinary Tourism Supply Chains: a Preliminary Examination. Journal of Travel Research (46), 289-299.

Solak, B. B. 2016. Sürdürülebilir Gastronomi Turizmine Bir Model: Sille Beldesi Örneği. Gazi Üniversitesi Turizm Fakültesi Dergisi (1), 1-12 (in Turkish).

Sormaz, Ü., Güneş, E. 2016. Traditional Culinary Museums: Samples from Turkey. International Journal of Humanities and Social Science Invention 5(6): 27-31.

Şahin, Ö., Aydın, A. 2017. A Cultural, Gastronomic, and Touristic Asset: The Kuşadası Oleatrium Olive and Olive Oil History Museum Case. Journal of Tourism and Gastronomy Studies 5(4): 180-199.

Şahinoğlu, Ş. 2015. Somut Olmayan Kültürel Miras Kavramına Farklı Bir Yaklaşım: Mutfak Müzeleri. Yayımlanmamış Yüksek Lisans Tezi, İstanbul Üniversitesi Sosyal Bilimler Enstitüsü, İstanbul (in Turkish).

Şener, O. 2016. Müzelerin Ekonomik Etkileri. İçinde: E. Şener (Editör). Beta Basım Yayım A.Ş., İstanbul, 1-236, (in Turkish).

Şimşek, N., Akdağ, G. 2017. Sürdürülebilir Gastronomi Turizmi Kapsamında Yeşil Nesil Restoranları İncelenmesi. International Journal of Social Science, (60), 351-368 (in Turkish).

Timothy, D. J. 2016. Introduction: Heritage Cuisines, Foodways and Culinary Traditions. In: D. J. Timothy (Ed.) Heritage Cuisines Traditions, identities and tourism. Routledge, London and New York, 1-24.

Williams, E. 2013. Food Museums. In: K. Albala (Ed.) Routledge International Handbook of Food Studies. Routledge, London and New York, 229-237.

Yağar, H. D. 2012. Antalya Mutfak ve Yemek Kültürü Müzesi Tasarımı. Yayımlanmamış Yüksek Lisans Tezi, Akdeniz Üniversitesi Sosyal Bilimler Enstitüsü, Antalya (in Turkish). 
Yeşilyurt, H., Arıca, R. 2018. Mutfak Müzesi Ziyaretçilerinin Deneyimlerinin İncelenmesi: Emine Göğüş Mutfak Müzesi Örneği. Türk Turizm Araştırmaları Dergisi 2(1), 60-70 (in Turkish).

Yıldız, Ö. E. 2016. Turistik Ürün Olarak Gastronomi. İçinde: H. Kurgun ve D. Bağıran Özşeker (Editörler) Gastronomi ve Turizm (Kavramlar - Uygulamalar - Uluslararası Mutfaklar Reçeteler). Detay Yayıncılık, Ankara, 25-44 (in Turkish).

Yılmaz, H., Şenel, P. 2014. Turistik Bir Çekicilik Olarak Gastronomi Müzeleri. 15. Ulusal Turizm Kongresi Bildiriler Kitabı, (499-510). Ankara: Gazi Üniversitesi, Turizm Fakültesi (in Turkish).

Yüncü, H. R. 2010. Sürdürülebilir Turizm Açısından Gastronomi Turizmi ve Perşembe Yaylası. İçinde: S. Şengel (Editör) Yerel Değerler ve Yayla Turizmi. 10. Aybastı-Kabataş Kurultayı, Detay Yayıncılık, Ankara, 27-34 (in Turkish).

\footnotetext{
訬㨫訬

Internet 1: http://www.kulturvarliklari.gov.tr/TR,43253/bakanligimiza-bagli-muzeler.html (10.02.2018)

Internet 2: http://www.foodmuseum.com/foodheritage/food-books (11.03.2018)

Internet 3: https://commons.wikimedia.org/wiki/File:Exterior_of_the_Amsterdam_Cheese_ Museum,_Amsterdam_(2018).jpg (16.02.2019)

Internet 4: https://commons.wikimedia.org/wiki/File:Museodellolivo2.JPG (16.02.2019)

Internet 5: https://commons.wikimedia.org/wiki/File:Salzmuseum_Eingang.jpg (16.02.2019)

Internet 6: https://commons.wikimedia.org/wiki/File:168_2015_o7_16_S\%C3\%BClfmeisterstra\%C $3 \% 9$ Fe_1.jpg (16.02.2019)

Internet 7: http://www.turkpatent.gov.tr/TURKPATENT/geographicalRegisteredList/ (20.02.2018)

Internet 8: http://www.dulkadiroglu.bel.tr/i/mutfak-muzesi.html (10.03.2018)
} 